\title{
LUT
}

University

\section{Effectiveness of innovation capability development methods}

Ukko Juhani, Saunila Minna, Parjanen Satu, Rantala Tero, Salminen Juho, Pekkola Sanna, Mäkimattila Martti

This is a Post-print version of a publication

published by Taylor \& Francis

in Innovation : Organization \& Mangement

DOI: $10.1080 / 14479338.2016 .1233824$

Copyright of the original publication: (c) Taylor \& Francis

Please cite the publication as follows:

Ukko J., Saunila M., Parjanen S., Rantala T., Salminen J., Pekkola S., Mäkimattila M. (2016). Effectiveness of innovation capability development methods. Innovation : Organization \& Mangement, vol. 18, issue 4. pp. 513-535. DOI: 10.1080/14479338.2016.1233824

This is a parallel published version of an original publication. This version can differ from the original published article. 


\section{Effectiveness of innovation capability development methods}

The literature presents numerous methods and practices for facilitating organizational innovation capabilities. Less attention has been paid to indicating the actual impact of these methods on different aspects of innovation capability. The current study focuses on this issue by examining three methods developed to facilitate organizational innovation capabilities and their effects on different aspects of innovation capabilities. The study uses the multiple-case study approach, focusing on the effects of the Handbook of Innovation, Theatre-based methods, and an Innovation Session on innovation capability and how these effects appear in different organizational contexts. The essential issues related to the positive effects of the methods on innovation capability are explored. The study contributes to the literature by showing that innovation capability can be developed by utilizing different kinds of participative methods. In addition, the study contributes to the current literature by presenting what kind of methods can be used to develop certain aspects of innovation capability and how the development works could be organized. The outcome helps managers of organizations select the most suitable method for developing innovation capability. This selection depends on the aspect of the innovation capability that the organization wishes to develop. The study also presents important issues that should be considered when developing innovation capability.

Keywords: Innovation capability, Innovation, Effectiveness, Method, Leadership, Ideation, Work climate, Know-how development, Regeneration, External knowledge, Individual activity

\section{Introduction}

The ability to innovate is a critical success factor for the growth and future performance of firms, and is seen as the only means by which companies can sustain competitive advantage (Carayannis \& Provance, 2008; Muller, Välikangas, \& Merlyn, 2005). Linking strategy with innovation activities, together with a shared vision of innovation, is essential when creating innovation capability (e.g., Davila, Epstein, \& Shelton, 2006; Lawson \& Samson, 2001; Saunila, 2016; Skarzynski \& Gibson, 2008). Prior literature has presented elements that make up innovation capability (e.g., Kallio, Kujansivu, \& Parjanen, 2012; Lawson \& Samson, 2001; Perunović, Mefford, Christoffersen, McIvor, \& Falls, 2016; Saunila, 2014, 2016; Saunila \& 
Ukko, 2012; Skarzynski \& Gibson, 2008). Skarzynski and Gibson (2008) emphasize the sharing of a common vision of innovation among the leaders and the organization, a disciplined approach to building innovation capabilities across the organization, support tools to enable an idea-generating pipeline and portfolio management, a collaborative open culture, and incentives that reward the challenging of current actions.

Bringing innovation to every workstation requires practical tools, processes, and mechanisms that the employees can use day-to-day to turn the innovation into the organization's capability (Skarzynski \& Gibson, 2008). The current literature presents numerous methods and practices for facilitating organizational innovation capabilities. However, less attention has been paid to indicating the actual effects of different methods on different dimensions of innovation capability. The current study explores this issue by examining three methods developed to facilitate organizational innovation capabilities and their effects on different dimensions of innovation capabilities. The methods are the Handbook of Innovation (Salminen, Saunila, \& Mäkimattila, 2011), innovation session (Melkas, Uotila, \& Tura, 2016; Parjanen, 2012a, 2012b), and theatre-based methods (Pässilä, Oikarinen, \& Vince, 2012). These methods have been used in private and public organizations. For example, the methods have been used in a company that manufactures and develops products for the wood industry worldwide and a public organization that produces and provides social and healthcare services. Some studies suggest that the methods may have different results in public and private sector organizations, as, for example, resistance to changes is usually perceived as stronger in public organizations (e.g., Rantanen, Kulmala, Lönnqvist, \& Kujansivu, 2007). The study clarifies what effects these methods have on the different dimensions of innovation capabilities in different organizational contexts. In the interpretation of the results, the following definition is used (Saunila, 2014; Saunila \& Ukko, 
2013, 2014): Innovation capability can be divided into seven dimensions: a participatory leadership culture, ideation and organizing structures, the work climate and well-being, knowhow development, regeneration, external knowledge, and individual activity.

As innovation is one of the main business processes of an organization, managing innovation is seen as a structured process instead of a hope-based strategy (Janssen et al., 2011). The present study contributes to prior theory of innovation management by investigating whether the exploitation of structured methods will advance the dimensions of innovation capability. The study shows that it is possible to develop different dimensions of innovation capability by exploiting these methods. The study also shows the important factors that should be taken into account when these methods are utilized and which methods affect the various aspects of the innovation capability. The effects on a specific dimension of innovation capability seem to depend on the method, instead of on the organizational context. The study also reveals numerous issues related to positive effects of the methods.

\section{Literature review}

\section{Development of organizational innovation capability}

An economy or a viable business environment with competitive organizations cannot exist without innovation (Haga, 2005). Developing innovation capability is considered essential for successful organizations (e.g., Lillis, Szwejczewski, \& Goffin, 2015; Saunila, 2016; Saunila \& Ukko, 2012, 2014; Tang, Wang, \& Tang, 2015; Tidd, Bessant, \& Pavitt, 2005). Without continuous development and innovation, disruptions in internal and external conditions would destroy the balance between supply and demand in the market. The definition of innovation includes novelty, commercialization, and/or implementation. According to Tidd et al. (2005), innovation is the process of turning opportunities into new ideas and putting these new ideas into 
widely used practice. Ideas are necessary conditions for innovations. Ideas are a starting point, but they cannot be called innovative without further development efforts. In other words, if an idea has not been developed and transformed into a product, process, or service or has not been commercialized, it will not be classified as an innovation (Popadiuk \& Wei Choo, 2006).

Previously, innovation was guided by linear models, such as the technology-push model, in which the development, production, and marketing of new technology is assumed to follow a well-defined time sequence beginning with basic and applied research activities, involving a product development stage, and leading to production and possibly commercialization. However, the science push effect as the driving force of innovations is an exception rather than a rule in innovation processes (Schienstock \& Hämäläinen, 2001). Instead, innovations seem to presume such factors as the ability to interact, to learn collectively, and to build trusting relations between innovating partners (Harmaakorpi, 2004). For example, Agarwal and Selen (2009) stress that the outcome of the innovation is based on the collaboration and education of stakeholders. The socalled doing-using-interacting viewpoint examines the informal processes of learning and experience-based know-how (Fitjar \& Rodríguez-Pose, 2013; Jensen, Johnson, Lorenz, \& Lundvall, 2007; Parrilli \& Heras, 2016) and develops the capability to produce innovation, for example, through breaking organizational silos, advancing interpretative innovation processes, using customers and employees as innovation sources, and facilitating organizational learning (Harmaakorpi \& Melkas, 2012; Kallio et al., 2012). According to Agarwal and Selen (2009), managers should recognize the potential embedded in collaboration, learning, and management of creative ideas for strategic and operational benefits. Managers should take measures to inculcate and manage these skill sets to foster innovation. 
Although studies (e.g., Delgado-Verde, Martin-de Castro, \& Navas-López, 2011) have emphasized the role of management commitment as a driver for innovation capability related to product innovations, the importance of employees' input regarding companies' entire innovation performance has also been acknowledged in the literature (e.g., Bessant, 2003; Kesting \& Ulhøi, 2010). Suitable processes are needed to use employees' innovativeness (Desouza et al., 2009). Nevertheless, not all organizations are the same, and different organizations have different issues and approaches regarding innovation activities. Thus, different solutions are needed (Hansen \& Birkinshaw, 2007). Kaltoft et al. (2007) studied different approaches to collaborative improvement, namely, the bottom-up learning-by-doing approach, the top-down directed approach, and the non-directed approach, paying equal attention to concept building and experience gained from practice. According to that study, successful implementation of the collaborative improvement process requires elements of all three approaches: understanding and direction (the top-down approach), activity and learning (the bottom-up approach), and a genuine willingness to collaborate, based on trust and commitment (the key values of the third approach). Interactive innovation audits have been suggested as one way to improve employee-driven innovation (Hallgren, 2009). The current study examines the methods that focus on collaborative improvement of an organization's innovation capability. Innovation capability and the methods are presented in detail.

\section{Innovation capability}

Innovation capability has been the subject of several studies in innovation management. According to Lawson and Samson (2001), innovation capability is a theoretical framework that describes the actions that can improve the success of innovation activities. Thus, the definitions of innovation capability often concentrate on defining factors shared by innovative organizations. 
These factors are the dimensions that form an organization's capability to innovate. Previous literature has identified the key dimensions that form innovation capability (e.g., Foroudi, Jin, Suraksha, Melewar, \& Foroudi, 2016; Lawson \& Samson, 2001; Romijn \& Albaladejo, 2002; Saunila, 2014, 2016; Saunila \& Ukko, 2013, 2014; Skarzynski \& Gibson, 2008; Smith, Busi, Ball, \& van der Meer, 2008). However, innovation capability may not be a unitary set of attributes, meaning that different aspects may be needed to create different kinds of innovations (Francis \& Bessant, 2005).

In this paper, innovation capability is divided into seven dimensions (Saunila, 2014; Saunila \& Ukko, 2013, 2014). The dimensions are participatory leadership culture, ideation and organizing structures, work climate and well-being, know-how development, regeneration, external knowledge, and individual activity. This definition was chosen because it broadly covers the important dimensions of innovation capability. The dimensions that form innovation capability are presented below.

- The participatory leadership culture dimension is related to an organizational culture that supports innovation. The dimension reflects the overall atmosphere of the organization that supports and motivates innovation and a leadership culture that facilitates innovation.

- The ideation and organizing structures dimension includes the structures and systems that successful innovation requires. This includes the generation, development, and implementation of innovations, and the ways in which the organization's work tasks are organized.

- The work climate and well-being dimension includes employee well-being, and the work climate for innovation development, including collaboration and values. 
- The know-how development dimension points out that employee expertise plays an important role in the development of the organization's innovation capability. This includes knowledge as well as improvement in employee skills.

- The regeneration dimension reflects the organization's ability to learn from experience and to use that experience to create and develop innovations.

- The external knowledge dimension emphasizes the importance of exploiting external networks and knowledge for the overall organizational innovation capability. Thus, the dimension reflects the organization's internal capability to exploit external information in developing innovation capability.

- The individual activity dimension expresses that employees' individual innovation capability and activity are needed to form the organization's overall innovation capability. This factor includes the characteristics associated with higher innovation capability and employee motivation to foster innovations.

\section{Development methods for innovation capability}

\section{Handbook of Innovation}

In employee-driven innovation, the employees contribute actively and systematically to the innovation process (Kallio, 2012). Innovations can emerge from any part of the organization and any employee group (Kesting \& Ulhoi, 2010). A typical hindrance to employees' innovativeness is that individual employees do not see it as part of their job. Feeling responsible for generating ideas increases the activity versus "it is someone else's job" (Axtell et al., 2000; Kallio, 2012).

The purpose of the Handbook of Innovation method (Salminen et al., 2011) is to create a concept for an employee-driven innovation process. The Handbook engages employees in 
designing an innovation system inside the organization in a co-creative process with managers and researchers (Hyypiä \& Parjanen, 2013; Kallio, 2012; Parjanen, 2012b). The method consists of a diagnosis phase, workshops, and documentation. The diagnosis evaluates the organization's current innovation capability and identifies opportunities for development (e.g., Kallio et al., 2012). Interviews, surveys, and narratives can be used for collecting data. The results are analyzed and feedback provided to the organization (Kallio et al., 2012; Saunila, Kallio, Parjanen, \& Harmaakorpi, 2012).

The most important part of the model is the design of the workshops in which the innovation process is defined. The structure of the workshops is modular, allowing easy repetition of workshops and continuing from the results of the last session. The workshops last about four hours and are structured as follows:

1. Introduction of the participants

2. Short presentation of the workshop topic by a researcher

3. Discussion of pre-defined issues. Ideas are documented with sticky notes attached to corresponding cells on a large table drawn on a whiteboard

\section{Grouping of ideas}

5. Discussion of the results and decision making

6. Documentation of the results in the handbook by researchers

A template table drawn on a whiteboard guides the discussion of the issues at hand. The template contains themes to be discussed, short summaries of the diagnosis, and empty space for documenting ideas and decisions. The results are documented in the Handbook of Innovation. The document communicates the results to the participants during the development project. The Handbook evolves during the project and contains a concept for the innovation process. The 
creation of the Handbook can be understood as a participatory approach to innovation. This kind of approach builds on the idea that the individual is a part of the process, it is in the employees' self-interest to participate in innovation, and the starting point of the process is the experience of an individual, not the organization's process (Kallio, 2012; Parjanen, 2012b; Ukko \& Saunila, 2013). Ramaswamy and Gouillart (2010) also stress the bottom-up component of development.

\section{Theatre-based methods}

According to Lester and Piore (2004), innovation is often studied only as a decision-making and problem-solving process. From this perspective, innovation is defined as an analytical linear project with a well-defined beginning and end, aimed at solving existing problems. What if the issue does not exist yet but is more a result of incompleteness (Heikkinen, 2002) and illustrates the logic of drama and learning through the aesthetics of incompleteness and co-construction (Weick, 1995)? Innovation processes must also be affected by issues that cannot be "solved" or unified in a logical, linear, and analytical fashion. The goal of interpretative innovation is to discover new definitions. This process of sense making is understood to be a fragmented, ongoing, open-ended (and multi-voiced) process of dialogue that emphasizes interaction and communication (Lester \& Piore, 2004; Pässilä, 2012).

Understanding the dynamics that support innovation involves understanding the dynamics that get in the way of innovation. Theatre-based methods offer an approach for creating reflective spaces that can reveal the dynamics of innovation. In generating deeper and richer multi-voiced understanding, communicating individual and group views is the key (Pässilä

et al., 2012). Theatre-based methods offer means for expressing one's own and understanding others' worldviews, attitudes, and behavior, and thus favor experiential and transformative learning. Schreyögg (2001) states that theatre-based methods can make things move but cannot 
produce predictable results. With the help of theatre, for example, employees may talk about their practices, behaviors, and feelings in a way that constructs a cultural space for a new innovation (Pässilä, Melkas, \& Uotila, 2013; Pässilä, Oikarinen, \& Kallio, 2013; Pässilä, Oikarinen, Parjanen, \& Harmaakorpi, 2013).

Theatre-based methods apply narrative and dramaturgical interventions and implement practical actions that concentrate on sharing, repeating, amplifying, and interpreting everyday work processes and social practices to make them visible and to reinterpret and resequence them. Theatre-based methods involve several interactive phases (Pässilä, 2012; Torquet, Friis, \& Buur, 2013). First, to plot realities, the views and practices of each community or work group are articulated and reflected. This is facilitated by storytelling methods and theatrical pictures (Pässilä, 2012; Pässilä, Oikarinen, \& Kallio, 2013). Then the stories are analyzed and devised as performative theatre scenes. The scenes are played back to the narrators as a theatrical performance in a theatre session. The focus of the theatre session is to construct common understanding by using a practical problem as a boundary object. During the session, several theatrical techniques are used, such as image theatre, forum theatre, and collective scripting (Pässilä \& Oikarinen, 2014; Pässilä et al., 2012; Pässilä, Oikarinen, Parjanen, et al., 2013; Torquet et al., 2013).

\section{Innovation session}

Open innovation is a phenomenon that has become increasingly important for practice and theory over the last few years (Dahlander \& Gann, 2010; Enkel, Gassmann, \& Chesbrough, 2009; Huizingh, 2011). The innovation processes of an organization also need to be adapted to the changing characteristics of innovation activities, where external knowledge and actors are an 
increasing part of the processes. One example of an open innovation tool that draws on input from outside parties is the innovation session method.

The purpose of the innovation session is to combine regional and inter-regional expertise to benefit the organizations' innovation measures. Each innovation session process is always planned individually and considers the organization's background and needs. Innovation session processes are used in the private and public sectors. The results of the innovation session processes are new business ideas, service concepts, enhanced products, product development projects, operations models, clarifications, and strategies (Aula \& Harmaakorpi, 2008; Melkas et al., 2016; Parjanen, 2012b).

The innovation session process begins with preparation. First, the current situation of the organization or a group of related organizations is analyzed. This gives an idea of the current state of the organization, the future challenges it faces, and where the potential for innovation may lie. During the preparation, the session design and work methods are chosen by the brokers of the intermediate organizations. Independent experts are also selected to make key external contributions to the innovation sessions. The working questions and the structure of the innovation session day are tested with a representative of the client organization before the session. The purpose of the preparation is to answer the following questions: What will the client organization want, and how ready is it to change its current action (Parjanen, 2012b; Parjanen, Harmaakorpi, \& Frantsi, 2010)?

The one-day innovation session includes experts from the client organization, often experts from the world of science, and members of intermediate organizations. The members of the intermediate organizations include a creativity operator, brokers, and a secretary. The sessions are arranged for a heterogeneous group of people, often consisting of representatives of 
different sectors, hierarchical positions within the organization, professions, and academia (e.g., Linna, Melkas, \& Hennala, 2010). The combined input of the client organization and the experts, together with the brokers, is used to generate innovative ideas for the organization to consider. The ideas recorded in an innovation session should be considered starting points, raw material for potential innovation, not finished products or services. In many innovation session processes, there is a post- innovation session or smaller meetings between the representatives of the organization and the experts or new innovation partners (Parjanen, 2012a; Parjanen et al., 2010). The purpose of the innovation session is not only to generate ideas but also to create relationships and networks among the participants in the innovation system (Melkas et al., 2016).

\section{Research approach}

\section{Methodology}

The study uses the multiple-case study approach. The case study strategy is used when the researcher seeks answers to how and why questions and further in-depth understanding of the phenomenon under discussion (Yin, 2003). The case study approach is justified when the researcher has little control over the events being studied, when the object of the study is a contemporary phenomenon in a real-life context, when boundaries between the phenomenon and the context are not clear, or when using multiple sources of evidence is desirable (Yin, 2003). Based on the logic underlying the use of multiple-case studies (Yin, 2003), some cases are predicted to produce similar results and some contrasting results. To ensure reliability, two (or more) individuals should code the same data independently. The degree of agreement between the coders is a measure of reliability in coding (Ghauri \& Grønhaug, 2002). The current study focuses on what effects the Innovation Handbook, theatre-based methods, and innovation session have on different dimensions of innovation capability and how these effects occur in different 
organizational contexts. The study also explores important issues related to the positive effects of the methods on innovation capability. The assumption was that a certain development method would have an effect on certain dimensions of innovation capability. The other assumption was that the methods might have different results in public and private sector organizations, as, for example, resistance to changes is usually perceived as stronger in public organizations (e.g., Rantanen et al., 2007). Therefore, public and private sector organizations were selected as the case organizations for the current study. The study uses multiple data sources, for example, interviews, observations, and questionnaires, to increase the reliability of the results (data triangulation). The effectiveness of the methods was evaluated at the beginning, during, and after the development activities. In the analysis, the first step was to analyze the effects of the methods in single cases, after which the methods and the context were cross-case analyzed. The results

were interpreted against the dimensions of innovation capability (adapted from Saunila, 2014; Saunila \& Ukko, 2013, 2014). The data analysis was conducted by two or more researchers independently to increase the credibility of the study, after which a common view was discussed (researcher triangulation).

\section{Case description and data gathering}

Case organization 1a is part of a bigger group that provides services for the supermarket, service station store and fuel, department store and speciality store, tourism and hospitality, automotive and accessories, and agricultural industries. The case organization is a department store that sells lifestyle products. The organization's main product areas are plants and garden and interior decoration, renovation, and building. In the case organization, a customer can buy interior decorating equipment and tools as well as house packages. In addition, store-specific services, 
such as garden design and interior decorating design, are available. The case organization employs 55 individuals.

Case $1 \mathrm{~b}$ operates in a branch of the media industry. The media industry is facing a major technological change, and understanding customers' needs is now more important than ever (Mäkimattila, Saunila, \& Salminen, 2014; Storsul \& Krumsvik, 2013). In the media industry, it is typical to innovate as part of everyday work, instead of in centralized research and development units. The case company noticed a slow decline in the traditional business model in 2006. The organizational structure was changed to a matrix organization in 2009 , and a new position that was responsible for innovation activities was created. The person in this position contacted the university researchers and initiated a year-long development project.

Case 1c is a public organization that produces and provides social and healthcare services. The organization's operational model is pioneering in the social and healthcare sector. The organization operates in five product areas and offers services for the inhabitants of five municipalities. The case organization has a long history of development projects. The project on which this paper is based concentrates on exploiting employees' ideas better in everyday work.

Case $2 \mathrm{a}$ is an organization that manufactures and develops products for the wood industry worldwide. The wood industry is in a challenging situation due to the current restructuring in the global economy. The former solutions, in which competitiveness was sought primarily by investing in new technology and capacity, may no longer be sufficient. Therefore, the target organization reorganized and adjusted its business operations and business units. The changes were massive, causing some uncertainty and confusion among the personnel. For example, employees found it hard to understand the organization's new strategy and its connection to their 
own work. This was the main reason for starting a development project with the university researchers.

Case $2 \mathrm{~b}$ is a public dental healthcare organization. The organization produces dental healthcare services for people of all ages. During the last few years, the number of non-cancelled patient nonappearances among teenage customers has increased. To combat this problem, new ideas and solutions were needed. Another issue was to develop the dental healthcare service package to be more attractive to teenage customers and the target organization personnel. The development process with the university researchers started in the end of 2008.

Case $3 \mathrm{a}$ is part of a multi-field development corporation, which manufactures, develops, and markets different kinds of technochemical products, industrial chemicals, cleaning materials, and materials for institutional kitchens. The products are targeted for professional use. In addition, the company markets cleaning equipment and machines, as well as industrial and hygiene wiping products. The company has 10 employees and a network of agents. The company operates in Finland but is planning internationalization. The innovation session in the case company was organized in 2006. Before the innovation session, there was a change in the ownership of the company. The new owner needed new ideas for the company, as it had operated according to old models for a long time. Processing liquids and surfaces were chosen as the theme of the innovation session process. The old liquids were not efficient in the most demanding situations, aluminium processing had increased, and the company did not have a product for that. The company was also interested in increasing their knowledge of nanotechnology.

Case $3 \mathrm{~b}$ is a supplier of technology for the wood product industry worldwide. The company began operating by manufacturing inland waterway vessels and frame saws in 1908. 
Today, the company's core expertise lies in manufacturing processes for selected wood products. The company supplies mill-wide projects, and in these selected fields, the company is the global market leader. In 2009, the company had sales of roughly $€ 36.6$ million and 542 employees in Finland and abroad. The purpose of the innovation session in the case company was to find innovative ideas for producing veneer and wood drying processes. Another purpose was to test the innovation session method in the company and to find out in what kind of situations the method would be most appropriate. The innovation session process was conducted in 2008.

Case $3 c$ is the region of Päijät-Häme that has declared itself a mega-sports region. A logical continuation of this is for Päijät-Häme to become a mega-health-related sports region. Supporting residents' well-being by developing sports services and promoting health-related sports has been included as an objective in the Regional Strategy and the Strategy of Education. The Strategy of Health-Related Sports has been prepared as part of the Project for Reforming Public Services in cooperation with the municipalities of the region, sports organizations, and the national well-being network of the Regional Centre Program. The Päijät-Häme Sports Federation has overall responsibility for preparing the strategy. The preparation of the Strategy of HealthRelated Sports started in spring 2008 with an innovation session. The innovation session included a large group of participants from different sectors. The objective of the session was to find innovative solutions for practical health-related sport arrangements and implementation of the strategy.

The study uses data gathered from seven cases using three methods for developing innovation capability. A summary of the case descriptions, data-gathering, and analysis methods are presented in Table 1. The data-gathering themes and the sources are presented in Table 2. 
Table 1. Description of the data used in the study.

\begin{tabular}{|c|c|c|c|c|}
\hline & Case description & Development process & Data gathering & Data analysis \\
\hline \multicolumn{5}{|c|}{ Handbook of Innovation } \\
\hline $\begin{array}{l}\text { Case } \\
1 \mathrm{a}\end{array}$ & $\begin{array}{l}\text { Retail company operating } \\
\text { in the construction, } \\
\text { decoration, and gardening } \\
\text { fields } \\
\text { Approx. } 50 \text { employees }\end{array}$ & $\begin{array}{l}\text { Diagnosis with } 20 \text { interviews, } 3 \\
\text { narrative sessions, and a survey ( } 35 \\
\text { responses) } \\
4 \text { workshops (5-15 representatives) } \\
\text { Employees and management were } \\
\text { involved }\end{array}$ & $\begin{array}{l}\text { A feedback questionnaire; } \\
6 \text { interviews with } \\
\text { management and } \\
\text { employees }\end{array}$ & $\begin{array}{l}\text { Quantitative data analysis } \\
\text { with means and standard } \\
\text { deviations } \\
\text { Content analysis of } \\
\text { interview data }\end{array}$ \\
\hline $\begin{array}{l}\text { Case } \\
1 \mathrm{~b}\end{array}$ & $\begin{array}{l}\text { Media company that } \\
\text { includes several printed } \\
\text { papers, Internet services, } \\
\text { radio, and supportive units } \\
\text { such as printing and } \\
\text { distribution } \\
270 \text { employees }\end{array}$ & $\begin{array}{l}\text { Diagnosis with } 15 \text { interviews with key } \\
\text { personnel, a survey (147 responses), } \\
\text { and a workshop } \\
7 \text { workshops ( } 5-7 \text { participants) } \\
\text { Employees and management were } \\
\text { involved }\end{array}$ & $\begin{array}{l}\text { A feedback questionnaire; } \\
6 \text { interviews with } \\
\text { management and } \\
\text { employees }\end{array}$ & $\begin{array}{l}\text { Quantitative data analysis } \\
\text { with means and standard } \\
\text { deviations } \\
\text { Content analysis of } \\
\text { interview data }\end{array}$ \\
\hline $\begin{array}{l}\text { Case } \\
1 \mathrm{c}\end{array}$ & $\begin{array}{l}\text { Public organization that } \\
\text { produces and provides } \\
\text { social and healthcare } \\
\text { services. Five product } \\
\text { areas; offers services for } \\
\text { the inhabitants of five } \\
\text { municipalities. }\end{array}$ & $\begin{array}{l}\text { A survey targeted to all employees of } \\
\text { the organization ( } 226 \text { responses) } \\
5 \text { workshops ( } 4-14 \text { representatives) } \\
\text { Employees and management were } \\
\text { involved }\end{array}$ & $\begin{array}{l}\text { A survey with } 15 \\
\text { statements related to } \\
\text { different aspects of } \\
\text { innovation capability as } \\
\text { well as multiple-choice and } \\
\text { open questions }\end{array}$ & $\begin{array}{l}\text { Quantitative data analysis } \\
\text { with means and standard } \\
\text { deviations } \\
\text { Content analysis of open- } \\
\text { ended questions }\end{array}$ \\
\hline \multicolumn{5}{|c|}{ Theatre-based methods } \\
\hline $\begin{array}{l}\text { Case } \\
2 \mathrm{a}\end{array}$ & $\begin{array}{l}\text { Company manufactures } \\
\text { and develops products for } \\
\text { the wood industry } \\
\text { worldwide } \\
\text { Approx. } 950 \text { employees }\end{array}$ & $\begin{array}{l}\text { A survey targeted to all employees of } \\
\text { the organization ( } 48 \text { responses) } \\
7 \text { group interviews } \\
1 \text { theatre session } \\
\text { Employees and management were } \\
\text { involved }\end{array}$ & $\begin{array}{l}\text { A feedback questionnaire } \\
\text { after the sessions } \\
\text { A survey with statements } \\
\text { related to innovation } \\
\text { capability }\end{array}$ & $\begin{array}{l}\text { Content analysis of } \\
\text { feedback questionnaire } \\
\text { Quantitative data analysis } \\
\text { with means and standard } \\
\text { deviations }\end{array}$ \\
\hline $\begin{array}{l}\text { Case } \\
2 \mathrm{~b}\end{array}$ & $\begin{array}{l}\text { A public dental healthcare } \\
\text { organization, produces } \\
\text { dental healthcare services } \\
\text { for people of all ages } \\
\text { Approx. } 50 \text { employees }\end{array}$ & $\begin{array}{l}3 \text { group interviews during which } \\
\text { narratives were collected } \\
\text { Theatre session } \\
\text { Employees and management were } \\
\text { involved }\end{array}$ & $\begin{array}{l}\text { Interviews with } 8 \\
\text { management } \\
\text { representatives } \\
\text { A survey (whole } \\
\text { organization) } \\
\text { Observations made by the } \\
\text { researchers }\end{array}$ & $\begin{array}{l}\text { Content analysis of } \\
\text { interview data } \\
\text { Quantitative data analysis } \\
\text { with means and standard } \\
\text { deviations } \\
\text { Content analysis of } \\
\text { documented observations }\end{array}$ \\
\hline \multicolumn{5}{|c|}{ Innovation session } \\
\hline $\begin{array}{l}\text { Case } \\
3 \mathrm{a}\end{array}$ & $\begin{array}{l}\text { Manufactures, develops, } \\
\text { and markets different kinds } \\
\text { of technochemical products } \\
10 \text { employees and a } \\
\text { network of agents }\end{array}$ & $\begin{array}{l}\text { A preparation phase } \\
1 \text { innovation session }\end{array}$ & $\begin{array}{l}3 \text { interviews with members } \\
\text { of the case company } \\
\text { Group work and the } \\
\text { session report }\end{array}$ & $\begin{array}{l}\text { Content analysis of } \\
\text { interview data } \\
\text { Content analysis of group } \\
\text { work reports }\end{array}$ \\
\hline $\begin{array}{l}\text { Case } \\
3 b\end{array}$ & $\begin{array}{l}\text { A supplier of technology } \\
\text { for the wood product } \\
\text { industry worldwide } \\
542 \text { employees }\end{array}$ & $\begin{array}{l}\text { A preparation phase } \\
1 \text { innovation session } \\
\text { Meeting after the session }\end{array}$ & $\begin{array}{l}\text { A feedback questionnaire; } \\
3 \text { interviews with members } \\
\text { of the case company }\end{array}$ & $\begin{array}{l}\text { Content analysis of } \\
\text { feedback questionnaire } \\
\text { Content analysis of } \\
\text { interview data }\end{array}$ \\
\hline $\begin{array}{l}\text { Case } \\
3 c\end{array}$ & $\begin{array}{l}\text { The region of Päijät-Häme } \\
\text { that has a strategy of } \\
\text { supporting residents' well- } \\
\text { being by developing sports } \\
\text { services and promoting } \\
\text { health-related sports }\end{array}$ & $\begin{array}{l}\text { A preparation phase } \\
1 \text { innovation session } \\
\text { Supportive meeting after the session }\end{array}$ & $\begin{array}{l}\text { A feedback questionnaire } \\
\text { Group work done during } \\
\text { the session } \\
\text { The strategy of health- } \\
\text { related sports was used as } \\
\text { additional data }\end{array}$ & $\begin{array}{l}\text { Content analysis of } \\
\text { feedback questionnaire } \\
\text { Content analysis of group } \\
\text { work reports } \\
\text { Content analysis of } \\
\text { strategy reports }\end{array}$ \\
\hline
\end{tabular}


Table 2. Data-gathering themes and sources.

\begin{tabular}{|c|c|c|}
\hline & Data-gathering themes & Sources \\
\hline \multicolumn{3}{|c|}{ Handbook of Innovation } \\
\hline \multirow[t]{5}{*}{ Case 1a } & The handbook development process & \multirow{5}{*}{$\begin{array}{l}\text { Salminen et al. } \\
2011\end{array}$} \\
\hline & The results of the development process & \\
\hline & The impacts of the development process & \\
\hline & $\begin{array}{l}\text { Implementation (e.g., what practices have been introduced/entrenched as a result of the development } \\
\text { project, how the development process affected in innovation) }\end{array}$ & \\
\hline & $\begin{array}{l}\text { The functionality and effects of implemented solutions (e.g., what are the benefits of the implemented } \\
\text { practices, what factors were essential for the success of the development project) }\end{array}$ & \\
\hline \multirow[t]{5}{*}{ Case $1 \mathrm{~b}$} & The handbook development process & \multirow{5}{*}{$\begin{array}{l}\text { Salminen et al., } \\
\text { 2011; } \\
\text { Mäkimattila et } \\
\text { al., } 2014\end{array}$} \\
\hline & The results of the development process & \\
\hline & The impacts of the development process & \\
\hline & $\begin{array}{l}\text { Implementation (e.g., what practices have been introduced/entrenched as a result of the development } \\
\text { project, how the development process affected in innovation) }\end{array}$ & \\
\hline & $\begin{array}{l}\text { The functionality and effects of implemented solutions (e.g., what are the benefits of the implemented } \\
\text { practices, what factors were essential for the success of the development project) }\end{array}$ & \\
\hline \multirow[t]{3}{*}{ Case $1 \mathrm{c}$} & The results and impacts of the development process & \multirow{3}{*}{$\begin{array}{l}\text { Kallio et al., } \\
2012\end{array}$} \\
\hline & $\begin{array}{l}\text { Implementation (e.g., how is the handbook is implemented in daily activities, what kind of development } \\
\text { approaches are currently used in your work unit, how and in what contexts is the handbook used) }\end{array}$ & \\
\hline & $\begin{array}{l}\text { The functionality and effects of the implemented solutions (e.g., what are the benefits of implemented } \\
\text { practices) }\end{array}$ & \\
\hline \multicolumn{3}{|c|}{ Theatre-based methods } \\
\hline \multirow[t]{4}{*}{ Case 2a } & The development of organizational strategy through research-based theatre & \multirow{4}{*}{$\begin{array}{l}\text { Pässilä, 2012; } \\
\text { Pässilä et al., } \\
\text { 2013a; Pässilä } \\
\text { \& Oikarinen, } \\
\text { 2014 }\end{array}$} \\
\hline & The development of organizational culture and learning methods through research-based theatre & \\
\hline & The reflection through the theatre-based learning and development & \\
\hline & The results and impacts of the research-based theatre & \\
\hline \multirow[t]{5}{*}{ Case $2 b$} & The usefulness of the development process & \multirow{5}{*}{$\begin{array}{l}\text { Pässilä et al., } \\
\text { 2013a; Hyypiä, } \\
\text { Hennala, \& } \\
\text { Mellanen, } 2014\end{array}$} \\
\hline & The accomplishments in oral healthcare from the perspective of service renewal & \\
\hline & The changes in the ways the staff interacts with young customers in treatment situations. & \\
\hline & The results of the process (new operating models, services, networks) & \\
\hline & The direct and indirect effects of the development process at local, national, and international levels & \\
\hline \multicolumn{3}{|c|}{ Innovation session } \\
\hline \multirow[t]{7}{*}{ Case $3 \mathrm{a}$} & The decision to organize an innovation session in the case organization & \multirow{7}{*}{$\begin{array}{l}\text { Parjanen et al., } \\
\text { 2010; Parjanen, } \\
\text { 2012a, 2012b; } \\
\text { Melkas et al., } \\
2016\end{array}$} \\
\hline & The interviewee's own role in the innovation session process & \\
\hline & The role of outside expertise in the session & \\
\hline & The results of the session (what kind of ideas were generated and implemented) & \\
\hline & The ideas for improving the innovation session process & \\
\hline & The suitability of the working methods & \\
\hline & The atmosphere of the session & \\
\hline \multirow[t]{7}{*}{ Case $3 b$} & The decision to organize an innovation session in the case organization & \multirow{7}{*}{$\begin{array}{l}\text { Parjanen et al., } \\
\text { 2010; Parjanen, } \\
\text { 2012a, 2012b; } \\
\text { Melkas et al., } \\
2016\end{array}$} \\
\hline & The interviewee's own role in the innovation session process & \\
\hline & The role of outside expertise in the session & \\
\hline & The results of the session (what kind of ideas were generated and implemented) & \\
\hline & The ideas for improving the innovation session process & \\
\hline & The suitability of the working methods & \\
\hline & The atmosphere of the session & \\
\hline \multirow[t]{5}{*}{ Case $3 \mathrm{c}$} & The composition of the innovation session & \multirow{5}{*}{$\begin{array}{l}\text { Parjanen, } \\
\text { 2012a; } \\
\text { Harmokivi \& } \\
\text { Rantala, 2008 }\end{array}$} \\
\hline & The meaningfulness of the working methods & \\
\hline & The usefulness of the generated ideas & \\
\hline & The possibilities for new innovations & \\
\hline & $\begin{array}{l}\text { The usefulness of the innovation session for the client organization and for the participant's own } \\
\text { organization }\end{array}$ & \\
\hline
\end{tabular}




\section{Findings}

\section{Results in single organizations}

One way to benefit from internal knowledge is to capitalize on the knowledge and ideas of current employees, especially those who do not work in the internal R\&D department. An employee's engagement in innovative work behaviors requires the employee to be able and willing to be innovative (Amabile, 1997). In case 1a, the Handbook of Innovation method produced a novel pipeline for generating and evaluating the employees' ideas. The effects of the exploitation of the method were considered remarkable for the ideation and organization structures of the organization for several reasons. The method resulted in an electronic, formal, and simple employee suggestion system that contained well-defined stages for idea processing, possibilities for additional questions, and voting of ideas, as well as immediate feedback and communication that facilitate idea generation. The entire innovation process was documented in the Handbook of Innovation. One way to involve employees in creative processes is to give them the autonomy to define the ways and methods of how this should be done in the organization (Kallio, 2012; Parjanen, 2012a). Empirical evidence supports a positive relationship between autonomy and innovation. Autonomy and control over one's work have been found to correlate positively with employee engagement in innovative behaviors (Axtell et al., 2000; Shalley, Gilson, \& Blum, 2000). The possibility for employees to participate in the development process was important for successful implementation of the system. A formal procedure that ensures all submitted ideas are evaluated has increased idea generation, in other words, employees' individual activity.

In case $1 b$, the use of the Handbook of Innovation method influenced know-how development, ideation and organizational structures, the work climate, and well-being. The 
participants reported that they had learned new innovation-related knowledge and skills during the project. The participants' attitude toward innovation activities improved, and the effects lasted. Of the changes in the ideation and organizing structures, regular meetings of innovation agents are the most notable. The Handbook was also used when a new intranet was designed: There are more opportunities for collecting ideas, although the full-scale innovation process as described in the Handbook is not yet fully in place. The work climate and well-being were improved at least among the workshop participants, as they reported that the workshops were almost like therapy sessions. Morrison and Phelps (1999) suggest that an organizational climate that is considered safe and encourages risk-taking is important in motivating individuals to take the initiative. Initiative plays an important role in the innovation process: Individuals with initiative are more likely to adopt an active approach to work, to go beyond what is formally required in their jobs, and to have the persistence to follow their creative ideas through to implementation (Miron, Erez, \& Naveh, 2004). In addition, participants from different departments became friends during the project and were able to build trust through action. The possibility of employees interacting with people from different departments can provide information that is beneficial for generating ideas. In particular, information from employees with more diverse expertise provides connections to more remote facts and perspectives (Madjar, 2005; Yström, Aspenberg, \& Kumlin, 2015).

In case $1 \mathrm{c}$, the first aspect of innovation capability that the development method affected was the ideation and organizing structures. In the case organization, employees have started to write ideas down in meetings instead of just discussing them. The ideas are also evaluated constantly, and all employees whose work is related to the idea participate in the evaluation. Thus, the second dimension affected by the development method is individual activity. The 
employees are more active in discussing their ideas with managers (mostly concerning new ways of working). The Handwork of Innovation was probably a way to communicate the need for innovativeness to the employees. For example, Shalley (1995) found in her study that when individuals are told that creativity is important, they are more likely to behave creatively. The employees also felt that the observed problems were better taken care of, because they may have felt that they were entitled to do so in their work. In that sense, the process functioned as an empowering system. This was possible because two managers were present at almost every workshop. The Handbook of Innovation also brought innovation activities to the grassroots level, an important outcome of the development project (for more about this case, see Saunila et al., 2012).

The theatre-based method in case 2 a was useful for handling sensitive and uncomfortable issues. Due to the organizational changes, there was some uncertainty and confusion among the personnel. This may affect the employees' psychological safety. Psychological safety refers to a shared belief that the organization is a safe environment for taking interpersonal risks without needing to fear negative consequences (Edmondson, 1999). Empirical studies suggest that organizations with a climate of psychological safety are particularly conducive to innovativeness (Baer \& Frese, 2003). The mechanism through which this occurs includes reduced risks through presenting new ideas, a higher level of job involvement, and better team learning. During the theatre-based process, the participants were allowed to discuss their current problems and challenges. Sharing problems and experiences with colleagues gave the participants more understanding of and perspective on their own situation. This had a positive effect on the work climate and well-being. After the business units were reorganized, there was also some uncertainty in the leadership culture. For example, some employees did not know who their 
manager was, or they had not spoken with their manager. As the organization's managers were also involved in the development process, the gap between the employees and the managers narrowed. This had a positive effect on the participatory leadership culture. Supportive leadership is positively related to employee creativity (Oldham \& Cummings, 1996). The leaders may also provide encouragement for creativity by valuing individuals' contributions and showing confidence in the work group (Amabile, Conti, Coon, Lazenby, \& Herron, 1996).

In case $2 b$, the theatre-based method produced several new conceptual ideas for the target organization to regenerate its operations. These concepts included ideas for communicating with teenagers, interaction between the staff and clients, and preventive dental healthcare work. These ideas were further developed in latter phases of the whole project. In addition to new development ideas, external knowledge increased when the "voices" and "experiences" of the teenage clients were collected and visualized to the personnel of the target organization. According to Lettl, Herstatt, and Gemuenden (2006), there is valuable input from users in the early phases of innovation, especially in incremental innovations. Previous research has identified at least two main benefits of involving users in the ideation phase: Their ideas have a higher perceived user value, and under certain circumstances, they have more innovative ideas (Kristensson, Gustafsson, \& Archer, 2004). The experiences of these young clients also had a great effect on the birth of development ideas. Seeing young customers' experiences as "outsiders," the target organization employees felt that they understood the teenagers' behavior better. Not only the teenagers' but also the employees' experiences were gathered and analyzed. The participating personnel felt that having a chance to share their experiences with colleagues had positive effects on the work climate and well-being. 
The innovation session process in case company 3a brought outside expertise to the company. In the interviews, the role of external experts was especially valuable. Most innovation happens at the boundaries between disciplines or specialization (Carlile, 2002, 2004; Leonard, 1995). For example, Carlile $(2002,2004)$ has shown how the creation of new knowledge is facilitated when knowledge boundaries are crossed. The theme of the session was chosen so that in-house expertise was not enough. One interviewee commented on this as follows: "Let's say that the session generated about 15 trends of ideas... about half of which are under continuous consideration." The ideas were also implemented "right after that [session] a new product was developed and actually after that other new products were developed." The company networked with one of the companies that participated in the session. Product development took place in cooperation with the new innovation partner, and development no longer concentrated on one product only but on product families. The co-operation with one supplier also broadened and deepened after the session. The modernization of the processing liquids quickened because of the session. In the development, more emphasis was placed on the role of customers and their needs. The session also broadened know-know in the company, as one interviewee said that "[the session] broadened understanding about the issue and about the entire field. I now understand issues that I didn't understand earlier.”

The external experts were considered a richness of the innovation session of case company 3b. The participants saw that they got new ideas, and longer innovation processes based on the session were possible. According to the interviews, experts were seen as sparring partners and challenged existing ways of doing in the case company. However, external expertise was not used after the session. This implies difficulties in networking. The networking perspective on innovation emphasizes the importance of the connectivity of a heterogeneous 
group of actors and the importance of exploring and exploiting weak ties (Granovetter, 1973) and structural holes (Burt, 2004). The formation and functioning of these kinds of innovation networks can be problematic because of the existence of several challenges between innovating partners (Boschma, 2005; Parjanen, 2012a).

The problem in this innovation session was that the experts' knowledge about the case company was minor and one day was considered too brief to learn more about each other's expertise. Some company representatives were skeptical about whether the right experts were present, and some participants indicated that expertise was missing. If a group has the range of skills and knowledge required for a particular problem area, it is likely that they can tap this diversity to come up with a broader range of ideas than those with more limited diversity in knowledge (Paulus \& Brown, 2007).

It is impossible to say how many ideas were generated in the session, but the interviewees estimated that at least five ideas got a boost. According to the case company, the innovation session was one way to get a broader perspective on developing one product, and that goal was achieved. In addition, one technology field was activated after the session. According to the interviews, the innovation session stimulated the employees' thinking and confirmed the perception that the company should study other branches as sources for ideas and innovation and consider tapping into other technologies. However, some of the representatives of the case organization were not satisfied with the results of the session. They expected more radical ideas. It was also acknowledged that the company should have made a more detailed plan for how to proceed.

According to the participants, the innovation session of case $3 \mathrm{c}$ offered new knowledge and ideas for writing a strategy. The ideas of the innovation session were related to a wide range 
of sectors, such as urban planning, social and health issues, education, family and youth, research, and training. These ideas were used in the strategy. According to the feedback, the session offered also perspectives and ideas for the participants' own organization. However, it is impossible to say whether these ideas were implemented. The participants also thought that the session gave them the opportunity "to meet new people" and "network," because there was "diverse expertise" in the session. The session strengthened common understanding of the need for development of health-related sports in the region, as one of the participants wrote "a common tune was found." According to the participants, the session also inspired new ideas at the individual level. According to one participant, "there are always new and applicable ideas for one's own use."

\section{Summary of the results}

The results indicate that the different dimensions of innovation capability by using the three methods can be developed. The effects of the methods on different dimensions of innovation capability are presented in Table 3 to give an overall picture of the methods' effectiveness. To achieve a more accurate analysis, the effects of the methods on the case organizations are presented in numerical order, where number 1 indicates the most substantial effect, etc. The results of the Handbook of Innovation and innovation session methods seem to depend more on the methods than on the organizational context. The results (Table 3) indicate that the Handbook of Innovation contributes mainly to ideation and organizing structures and individual activity, although the starting point of the development and the adaptation of the method differed slightly between the organizations. Similarly, the innovation session method influenced the exploitation of external knowledge, as well as know-how development. The theatre-based method affects various dimensions of innovation capability, such as participatory leadership culture, work 
climate and well-being, regeneration, and external knowledge. This indicates that the effects may depend more on the organizational context and the starting point and the target of the development, compared to the other methods under investigation. The other explanation for the different effects may be the time scale, as in case $2 b$ the method and the evaluation afterward were conducted earlier compared to case $2 \mathrm{a}$. The current study does not indicate significant differences between the public and private sectors, and the differences regarding contextual features may have been associated with the organization size, structure, and culture, for example.

Table 3. Effects of the methods on innovation capability.

\begin{tabular}{|c|c|c|c|c|c|c|c|}
\hline & $\begin{array}{l}\text { Participatory } \\
\text { leadership } \\
\text { culture }\end{array}$ & $\begin{array}{l}\text { Ideation and } \\
\text { organizing } \\
\text { structures }\end{array}$ & $\begin{array}{l}\text { Work climate } \\
\text { and well- } \\
\text { being }\end{array}$ & $\begin{array}{l}\text { Know-how } \\
\text { development }\end{array}$ & Regeneration & $\begin{array}{l}\text { External } \\
\text { knowledge }\end{array}$ & $\begin{array}{l}\text { Individual } \\
\text { activity }\end{array}$ \\
\hline \multicolumn{8}{|c|}{ Handbook of Innovation } \\
\hline Case 1a & & 1 & & & & & 2 \\
\hline Case $1 b$ & & 2 & 3 & 1 & & & \\
\hline Case 1c & & 1 & & & & & 2 \\
\hline \multicolumn{8}{|c|}{ Theatre-based methods } \\
\hline Case $2 \mathrm{a}$ & 2 & & 1 & & & & \\
\hline Case $2 b$ & & & 3 & & 1 & 2 & \\
\hline \multicolumn{8}{|c|}{ Innovation session } \\
\hline Case $3 a$ & & & & 2 & & 1 & \\
\hline Case $3 b$ & & & & 2 & & 1 & \\
\hline Case 3c & & & & 2 & & 1 & 3 \\
\hline
\end{tabular}

As presented in Table 3, the three methods affect all seven dimensions of innovation capability to some extent. The methods are not mutually exclusive but complement each other. They seem to be suitable for private and public organizations.

\section{Discussion}

In this study, the effects of the Handbook of Innovation (Salminen et al., 2011), innovation session (Parjanen, 2012a, 2012b), and theatre-based (Pässilä et al., 2012) methods on different 
dimensions of innovation capability were examined. These are novel doing-using-interacting methods, which are informal processes of learning and experience-based know-how with an interest in developing the capability to produce innovations (cf. Harmaakorpi \& Melkas, 2012; Jensen et al., 2007). Although the current literature presents numerous methods and practices for facilitating organizational innovation capabilities, less attention has been paid to indicating the actual effects of these methods on different dimensions of innovation capability. According to the present study, innovation capability can be influenced by these methods in different ways.

A few issues behind the positive effects of the methods studied should be emphasized. Although the informal processes (e.g., Jensen et al., 2007; Parrilli \& Heras, 2016) and the casespecific adaptation of the methods have been emphasized, a certain procedure must be followed during the development activities. This procedure can be organized by the brokers of the intermediate organizations as suggested by Parjanen (2012a). Without the procedure and a broker, there is a danger that development with a new method does not differ from ordinary development, and tension between the different personnel groups may remain, for example. This also raises the question about the skills of the brokers to plan and manage the innovation process. This means the ability to understand innovations and their characteristics and sources, the ability to create a dialogical process with the client organization and other stakeholders, and the ability to translate innovation problems into a structured project with the vision and ability to understand the necessary capabilities, skills, and knowledge to solve the problem (Kolodny et al., 2001; Parjanen, 2012a).

The results also indicate the importance of the planning stage of the innovation process. Planning the process includes choosing the methods to work on, setting targets, and putting in place the key resources and mechanisms to accomplish the development effort (Khurana \& 
Rosenthal, 1997). Before launching a development project to enhance innovation capability, knowing how the innovation intervention should be targeted is essential. Kallio et al. (2012) suggest a procedure for locating the development targets of organizational innovation capability before making decisions about projects. The questionnaire created to measure innovation capability was used not only to assess the status of the innovation capability with the help of bottom-up knowledge of the current state of affairs but also as a diagnosis method for facilitating managers' decisions regarding where to target the development projects.

The results also indicate that a systematic method of proceeding seems to reduce the relevance of the organizational context regarding the results. Although Kaltoft et al. (2007) present that a successfully implemented collaborative improvement process requires equal elements from understanding and direction (the top-down approach), activity and learning (the bottom-up approach), and a genuine willingness to collaborate, based on trust and commitment (the key values of the third approach), our results emphasize willingness to collaborate with interactive communication as the most important issue during the development procedure. Contrary to some prior studies (e.g., Delgado-Verde et al., 2011), the study suggests that the role of management commitment as a driver for innovation capability could be emphasized not during the development project but after it, to ensure sustainable effectiveness of the results. However, this result is based on the current study, and to verify the result and its relevance, further research is needed. Furthermore, the results show that high coverage of employees who have an opportunity to participate in the development actions provides the most effective and sustainable results. This result seems to be in line with the findings of Kallio (2012), Parjanen (2012b), and Ramaswamy and Gouillart (2010). 
The study also revealed challenges for exploiting the methods. The methods focus on the fuzzy front end of the innovation process, and the effects may be momentary. Thus, examining what can be done when the active part of the development ends is important, to ensure sustainable effects. One answer may be management's commitment to continue with the development. Another challenge is employee turnover: how to maintain the effects of the development, if the intake and loss of staff are quick. The answer to this question may be high coverage of employees with the opportunity to participate in development actions. Finally, an important aspect is whether the methods are enough to develop all the dimensions of innovation capability. The study suggests that they are not, and thus, other methods need to be created and studied.

\section{Conclusions}

As a theoretical contribution to the literature of the fuzzy front end of the innovation process and further to the literature of doing-using-interacting processes, the study has shown that innovation capability can be developed by utilizing different kinds of participative methods. In addition, the study contributes to the current literature by presenting what kind of methods can be used to develop certain aspects of innovation capability and how the development works could be organized. A somewhat systematic procedure, a broker from an intermediate organization, and interactive communication, together with willingness to collaborate, management commitment after the active part of development, and high coverage of the employees participating in the development enable the most effective and sustainable results for the examined methods. Further, the results indicate that the development themes that the innovation capability development methods are intended to influence should be limited to a few key themes, and the 
connection to back-end innovation process and further performance needs to be justified and discussed.

The managerial implications of the study can be tied to the empirical evidence from the case organizations. The study has presented that by using the Handbook of Innovation method, organizations can develop their ideation and organizing structures and individual activities, and by using the innovation session method, organizations can exploit external knowledge and knowhow development. Theatre-based methods can be used in organizations to express their own and to understand others' worldviews, attitudes, and behavior, and thus favor experiential and transformative learning, which can have an effect on multiple dimensions of innovation capability.

The methods, as well as the evaluation of the effects, were used in different time phases, which is a weakness regarding the reliability of the results. However, the multiple data sources and the analysis made by a number of researchers strengthened the reliability of the results. For further research, more longitudinal research and more sophisticated evaluation methods are needed when examining the practices and methods for facilitating innovation capability.

\section{References}

Agarwal, R., \& Selen, W. (2009). Dynamic capability building in service value networks for achieving service innovation. Decision Sciences, 40(3), 431-475.

Amabile, T. (1997). Motivating creativity in organizations: On doing what you love and loving what you do. California Management Review, 40(1), 39-58. 
Amabile, T., Conti, R., Coon, H., Lazenby, J., \& Herron, M. (1996). Assessing the work environment for creativity. Academy of Management Journal, 39(5), 1154-1184.

Aula, P., \& Harmaakorpi, V. (2008). Innovative milieu - a view on regional reputation building: A case study of the Lahti urban region. Regional Studies, 42(4), 523-538.

Axtell, C., Holman, D., Unsworth, K., Will, T., Waterson, P., \& Harrington, E. (2000). Shopfloor innovation: Facilitating the suggestion and implementation of ideas. Journal of Occupational and Organizational Psychology, 39, 599-617.

Baer, M., \& Frese, M. (2003). Innovation is not enough: Climates for initiative and psychological safety, process innovations, and firm performance. Journal of Organizational Behavior, 24(1), 45-69.

Bessant, J. (2003). High-involvement innovation: Building and sustaining competitive advantage through continuous change. Chichester, England: Wiley.

Boschma, R. (2005). Proximity and innovation: A critical assessment. Regional Studies, 39, 6174.

Burt, R. (2004). Structural holes and good ideas. American Journal of Sociology, 110, 349-399.

Carlile, R. (2002). A pragmatic view of knowledge and boundaries: Boundary objects in new product development. Organization Science, 13, 442-455.

Carlile, R. (2004). Transferring, translating, and transforming: An integrative framework for managing knowledge across boundaries. Organization Science, 15, 555-568.

Carayannis, E. G., \& Provance, M. (2008). Measuring firm innovativeness: Towards a composite innovation index built on firm innovative posture, propensity and performance attributes. International Journal of Innovation and Regional Development, 1(1), 90-107. 
Dahlander, L., \& Gann, D. M. (2010). How open is innovation. Research Policy, 39, 699-709.

Davila, T., Epstein, M. J., \& Shelton, R. (2006). Making innovation work: How to manage it, measure it, and profit from it. Upper Saddle River, NJ: Wharton School.

Delgado-Verde, M., Martín-de Castro, G., \& Navas-López, J. E. (2011). Organizational knowledge assets and innovation capability: Evidence from Spanish manufacturing firms. Journal of Intellectual Capital, 12(1), 5-19.

Desouza, K., Dombrowski, C., Awazu, Y., Baloh, P., Papagari, S., Jha, S., \& Kim, J. (2009). Crafting organizational innovation processes. Innovation: Management, Policy \& Practice, 11(1), 6-33.

Edmondson, A. (1999). Psychological safety and learning behaviour in work teams. Administrative Science Quarterly, 44, 350-383.

Enkel, E., Gassmann, O., \& Chesbrough, H. (2009). Open R\&D and open innovation: Exploring the phenomenon. $R \& D$ Management, 39(4), 311-316.

Fitjar, R. D., \& Rodríguez-Pose, A. (2013). Firm collaboration and modes of innovation in Norway. Research Policy, 42(1), 128-138.

Foroudi, P., Jin, Z., Suraksha, G., Melewar, T. C., \& Foroudi, M. (2016). The impact of innovation capability and customer experience on reputation and loyalty. Journal of Business Research.

Francis, D., \& Bessant, J. (2005). Targeting innovation and implications for capability development. Technovation, 25(3), 171-183.

Ghauri, P., \& Grønhaug, K. (2002). Research methods in business studies: A practical guide (2nd ed.). London, England: FT Prentice Hall Europe. 
Granovetter, M. (1973). The strength of weak ties. American Journal of Sociology, 78, 13601380.

Haga, T. (2005). Action research and innovation in networks, dilemmas and challenges: Two cases. AI \& Society, 19, 362-383.

Hallgren, E. (2009). How to use an innovation audit as a learning tool: A case study of enhancing high-involvement innovation. Creativity and Innovation Management, 18(1), 48-58.

Hansen, M., \& Birkinshaw, J. (2007). The innovation value chain. Harvard Business Review, $85(6), 121-131$.

Harmaakorpi, V. (2004). Building competitive regional innovation environment - The regional development platform method as a tool for regional innovation policy. Espoo, Finland: Helsinki University of Technology, Department of Industrial Engineering and Management.

Harmaakorpi, V., \& Melkas, H. (2012). Epilogue. In H. Melkas \& V. Harmaakorpi (Eds.), Practice-based innovation: Insights, applications and policy implications (pp. 437-452). Heidelberg, Germany: Springer.

Harmokivi, P., \& Rantala, M. (Eds). (2008). Päijät-Hämeen terveysliikuntastrategia 2009-2020. Päijät-Hämeen liitto A174.

Heikkinen, H. (2002). Draaman maailmat oppimisalueina: draamakasvatuksen vakava leikillisyys [Drama worlds as learning areas - the serious playfulness of drama education]. Jyväskylä, Finland: University of Jyväskylä Studies in Education, Psychology and Social Research.

Huizingh, E. (2011). Open innovation: State of the art and future perspectives. Technovation, 31, $2-9$. 
Hyypiä, M., Hennala, L., \& Mellanen, L. (2014). The tooth troll story: Innovation process to improve oral health care. Raportit ja selvitykset-Reports. Lappeenranta, Finland: LUT Scientific and Expertise.

Hyypiä, M., \& Parjanen, S. (2013). Boosting creativity with transformational leadership in fuzzy front-end innovation processes. Interdisciplinary Journal of Information, Knowledge and Management, 8, 21-41.

Janssen, S., Moeller, K. \& Schlaefke, M. (2011). Using performance measures conceptually in innovation control. Journal of Management Control, 22(1), 107-128.

Jensen, M., Johnson, B., Lorenz, E., \& Lundvall, B.-A. (2007). Forms of knowledge and modes of innovation. Research Policy, 36(5), 680-693.

Kallio, A. (2012). Enhancing absorptive capacity in a non-research and development context. An action research approach to converting individual observations into organisational awareness. Acta Universitatis Lappeenrantaensis 477. Lappeenranta, Finland: Lappeenranta University of Technology, Lahti School of Innovation.

Kallio, A., Kujansivu, P., \& Parjanen, S. (2012). Locating the weak points of innovation capability before launching a development project. Interdisciplinary Journal of Information, Knowledge and Management, 7, 21-38.

Kaltoft, R., Boer, H., Caniato, F., Gertsen, F., Middel, R., \& Nielsen, J. S. (2007). Implementing collaborative improvement - top-down, bottom-up or both? International Journal of Technology Management, 37(3/4), 306-322.

Kesting, P., \& Ulhøi, J. (2010). Employee-driven innovation: Extending the license to foster innovation. Management Decision, 48(1), 65-84. 
Khurana, A., \& Rosenthal, S. R. (1997). Integrating the fuzzy front end of new product development. Sloan Management Review, 38(2), 103-120.

Kolodny, H., Stymne, B., Shani, R., Figuera, J.R. \& Lillrank, P. (2001). Design and policy choices for technology extension organizations. Research Policy, 30(2), 201-225.

Kristensson, P., Gustafsson, A., \& Archer, T. (2004). Harnessing the creative potential among users. Journal of Product Innovation Management, 21(1), 4-14.

Lawson, B., \& Samson, D. (2001). Developing innovation capability in organisations: A dynamic capabilities approach. International Journal of Innovation Management, 5(3), $377-400$.

Leonard, D. (1995). Wellsprings of knowledge. Building and sustaining the sources of innovation. Boston, MA: Harvard Business School Press.

Lester, R., \& Piore, M. (2004). Innovation the missing dimension. London, England: Harvard University Press.

Lettl, C., Herstatt, C., \& Gemuenden, H. G. (2006). User's contributions to radical innovation: Evidence from four cases in the field of medical equipment technology. $R \& D$ Management, 36(3), 251-272.

Lillis, B., Szwejczewski, M., \& Goffin, K. (2015). The development of innovation capability in services: Research propositions and management implications. Operations Management Research, 8(1-2), 48-68.

Linna, P., Melkas, H., \& Hennala, L. (2010). Designing and implementing regional innovation policy in the public sector: Tools for triggering organisational process innovation. International Journal of Innovation and Regional Development, 2(4), 281-303. 
Madjar, N. (2005). The contributions of different groups of individuals to employees' creativity. Advances in Developing Human Resources, 7(2), 182-206.

Melkas, H., Uotila, T., \& Tura, T. (2016). Policies of related variety in practice: The case innovation session method. European Planning Studies, 24(3), 489-510.

Miron, E., Erez, M., \& Naveh, E. (2004). Do personal characteristics and cultural values that promote innovation, quality, and efficiency compete or complement each other? Journal of Organizational Behavior, 25(2), 175-199.

Morrison, E., \& Phelps, C. (1999). Taking charge at work: Extra-role efforts to initiate workplace change. Academy of Management Journal, 42, 403-419.

Muller, A., Välikangas, L., \& Merlyn, P. (2005). Metrics for innovation: Guidelines for developing a customized suite of innovation metrics. Strategy \& Leadership, 33(1), 3745.

Mäkimattila, M., Saunila, M., \& Salminen, J. (2014). Interaction and innovation - Reframing innovation activities for matrix organization. Interdisciplinary Journal of Information, Knowledge and Management, 9, 131-152.

Oldham, G., \& Cummings, A. (1996). Employee creativity: Personal and contextual factors at work. Academy of Management Journal, 39, 607-634.

Parjanen, S. (2012a). Creating possibilities for collective creativity. Brokerage functions in practice-based innovation. Acta Universitatis Lappeenrantaensis 474. Lappeenranta, Finland: Lappeenranta University of Technology, Lahti School of Innovation.

Parjanen, S. (2012b). Innovation sessions as sources of new ideas. International Journal of Innovation and Learning, 11(4), 352-368. 
Parjanen, S., Harmaakorpi, V., \& Frantsi, T. (2010). Collective creativity and brokerage functions in heavily cross-disciplined innovation processes. Interdisciplinary Journal of Information, Knowledge and Management, 5, 1-21.

Parrilli, M. D., \& Heras, H. A. (2016). STI and DUI innovation modes: Scientific-technological and context-specific nuances. Research Policy, 45(4), 747-756.

Paulus, P., \& Brown, V. (2007). Toward more creative and innovative group idea generation: A cognitive-social-motivational perspective of brainstorming. Social and Personality Psychology Compass, 1, 248-265.

Perunović, Z., Mefford, R., Christoffersen, M., McIvor, R., \& Falls, D. (2016). An analysis of vendor innovation capability in the contract electronics manufacturing industry. Production Planning \& Control, 1-13.

Popadiuk, S., \& Wei Choo, C. (2006). Innovation and knowledge creation: How are these concepts related? International Journal of Information Management, 26(4), 302-312.

Pässilä, A. (2012). A reflexive model of research-based theatre. Processing innovation at the crossroads of the theatre, reflection and practice-based innovation. Acta Universitatis Lappeenrantaensis 492. Lappeenranta, Finland: Lappeenranta University of Technology.

Pässilä, A., Melkas, H., \& Uotila, T. (2013). Facilitating collaborative knowledge creation by using "Research-Based Theatre" in organizational innovation: Experiences from a Finnish wood-processing company. Futures, 47, 59-68.

Pässilä, A., \& Oikarinen, T. (2014). Research-based theatre as a facilitator for organisational learning. In P. Meusburger, A. Berthoin Antal, \& L. Suarsana (Eds.), Learning organizations: Extending the field (pp. 203-221). Dordrecht, the Netherlands: Springer Verlag. 
Pässilä, A., Oikarinen, T., \& Kallio, A. (2013). Creating dialogue by storytelling. Journal of Workplace Learning, 25(3), 159-177.

Pässilä, A., Oikarinen, T., Parjanen, S., \& Harmaakorpi, V. (2013c). Interpretative dimension of user-driven service innovation: Forum theatre in facilitating renewal in Finnish public health care. Baltic Journal of Management, 8(2), 166-182.

Pässilä, A., Oikarinen, T., \& Vince, R. (2012). The role of reflection, reflection on roles: Practice-based innovation through theatre-based learning. In H. Melkas \& V. Harmaakorpi (Eds.), Practice-based innovation: Insights, applications and policy implications (pp. 173-191). Heidelberg, Germany: Springer.

Ramaswamy, V., \& Gouillart, F. (2010). The power of co-creation. New York, NY: Free Press.

Rantanen, H., Kulmala, H. I., Lönnqvist, A., \& Kujansivu, P. (2007). Performance measurement systems in the Finnish public sector. International Journal of Public Sector Management, 20(5), 415-433.

Romijn, H., \& Albaladejo, M. (2002). Determinants of innovation capability in small electronics and software firms in southeast England. Research Policy, 31(7), 1053-1067.

Salminen, J., Saunila, M., \& Mäkimattila, M. (2011, September). A process for developing employee-driven innovation processes. Paper presented at 12th International CINet Conference Continuous Innovation: Doing More with Less, Aarhus, Denmark.

Saunila, M. (2014). Innovation capability for SME success: Perspectives of financial and operational performance. Journal of Advances in Management Research, 11(2), 163-175.

Saunila, M. (2016). Performance measurement approach for innovation capability in SMEs. International Journal of Productivity and Performance Management, 65(2), 162-176. 
Saunila, M., Kallio, A., Parjanen, S., \& Harmaakorpi, V. (2012, September). Innovation manual designed by employees - Case study on the experiences and effects. Paper presented at the 13th International CINet Conference - Continuous Innovation Across Boundaries, Rome, Italy.

Saunila, M., \& Ukko, J. (2012). A conceptual framework for the measurement of innovation capability and its effects. Baltic Journal of Management, 7(4), 355-375.

Saunila, M., \& Ukko, J. (2013). Facilitating innovation capability through performance measurement: A study of Finnish SMEs. Management Research Review, 36(10), 9911010.

Saunila, M., \& Ukko, J. (2014). Intangible aspects of innovation capability in SMEs: Impacts of size and industry. Journal of Engineering and Technology Management, 33, 32-46.

Schienstock, G., \& Hämäläinen, T. (2001). Transformation of the Finnish innovation system: A network approach. Helsinki, Finland: Sitra.

Schreyögg, G. (2001). Organizational theatre and organizational change. Retrieved from http://www.wiwiss.fuberlin.de/w3/w3schrey/english/index.htm

Shalley, C. (1995). Effects of coaction, expected evaluation and goal setting on creativity and productivity. Academy of Management Journal, 38, 483-503.

Shalley, C., Gilson, L., \& Blum, T. (2000). Matching creativity requirements and the work environment: Effects on satisfaction and intentions to leave. Academy of Management Journal, 43, 215-223.

Skarzynski, P., \& Gibson, R. (2008). Innovation to the core: A blueprint for transforming the way your company innovates. Boston, MA: Harvard Business School Press. 
Smith, M., Busi, M., Ball, P., \& van der Meer, R. (2008). Factors influencing an organisation's ability to manage innovation: A structured literature review and conceptual model. International Journal of Innovation Management, 12(4), 655-676.

Storsul, T., \& Krumsvik, A. H. (2013). What is media innovation? In T. Storsul \& A. H. Krumsvik (Eds.), Media innovations. A multidisciplinary study of change (pp. 13-26). Gøteborg, Sweden: Nordicom.

Tang, T. W., Wang, M. C. H., \& Tang, Y. Y. (2015). Developing service innovation capability in the hotel industry. Service Business, 9(1), 97-113.

Tidd, J., Bessant, J., \& Pavitt, K. (2005). Managing innovation: Integrating technological, market and organizational change (2nd ed.). Chichester, England: Wiley.

Torquet, R., Friis, P., \& Buur, J. (2013, June). User ethnography as theatre. Paper presented at the Participatory Innovation Conference, Lahti, Finland.

Ukko, J., \& Saunila, M. (2013). The role of reflection in facilitating and assessing innovativeness. Journal of Technology Management \& Innovation, 8(4), 170-176.

Weick, K. (1995). Sensemaking in organisations. London, England: Sage.

Yin, R. K. (2003). Case study research, design and methods 3rd ed., Applied social research methods series. Thousand Oaks, CA: Sage.

Yström, A., Aspenberg, H., \& Kumlin, A. (2015). Exploring the creative climate in an open innovation arena. European Journal of Innovation Management, 18(1), 70-85. 